\title{
Bacterial microflora of the upper gastrointestinal tract in infants without diarrhoea
}

\author{
D. N. CHALLACOMBE, JUDITH M. RICHARDSON, and CHARLOTTE M. ANDERSON \\ From the Institute of Child Health, University of Birmingham
}

\begin{abstract}
Challacombe, D. N., Richardson, J. M., and Anderson, C. M. (1974). Archives of Disease in Childhood, 49, 264. Bacterial microflora of the upper gastrointestinal tract in infants without diarrhoea. The upper gastrointestinal microflora has been studied by intubation in a group of infants without diarrhoea. The aerobic flora of the nose and throat, and the aerobic and anaerobic flora of the stomach and duodenum have been defined. Prolonged duodenal intubation has been shown to increase the number of coliforms isolated and bacteriological findings after prolonged intubation should therefore be interpreted with care.
\end{abstract}

Many accounts have appeared in published reports regarding the nature of the microflora in the normal adult small intestine, and the subject has been recently reviewed by Donaldson (1968) and by Gorbach (1971). Some workers have reported that the upper small intestine in adults is invariably sterile (Shiner, Waters, and Gray, 1963), while others have described a constant but sparse Grampositive flora consisting mainly of staphylococci, streptococci, aerobic lactobacilli, diphtheroids, and fungi (Gorbach et al., 1967). Kalser et al. (1966) and Hamilton et al. (1970) also found low concentrations of coliforms in addition to those organisms.

The small intestinal microflora has rarely been studied in normal infants and children (Davison, 1925; Barbero et al., 1952; Anderson and Langford, 1958). The improvement of techniques for obtaining small intestinal juice by intubation (Rhea and Kilby, 1970) and the improvement of anaerobic culture methods (Drasar, 1967) justifies reexamination of the subject, and a qualitative and quantitative study of the aerobic and anaerobic microflora of the upper gastrointestinal tract in a group of 13 infants has been done.

As objections have been raised to the use of long tube methods for obtaining samples of intestinal juice (Cregan and Hayward, 1953) and bacteriological differences may arise from variation in sampling and culture techniques (Hamilton et al., 1970), the effect of prolonged intubation on the duodenal microflora has also been studied.

Received 4 September 1973.
TABLE I

Details of infants studied

\begin{tabular}{|c|c|c|c|}
\hline Case no. & $\begin{array}{c}\text { Age } \\
\text { (mth) }\end{array}$ & Sex & Diagnosis \\
\hline $\begin{array}{r}1 \\
2 \\
3 \\
4 \\
5 \\
6 \\
7 \\
8 \\
9 \\
10 \\
11 \\
12 \\
13\end{array}$ & $\begin{array}{l}2 \text { wk } \\
1 \\
5 \text { wk } \\
6 \text { wk } \\
2 \\
3 \\
3 \\
4 \\
4 \\
5 \\
6 \\
6 \\
10\end{array}$ & $\begin{array}{l}M \\
M \\
M \\
M \\
M \\
\text { F } \\
\text { F } \\
\text { F } \\
\text { F } \\
\text { M } \\
\text { M } \\
\text { F } \\
\text { M }\end{array}$ & $\begin{array}{l}\text { Inguinal hernia } \\
\text { Feeding problem } \\
\text { Feeding problem } \\
\text { Congenital heart disease } \\
\text { Congenital heart disease } \\
\text { Feeding problem } \\
\text { Feeding problem } \\
\text { Leiomyoma of tongue } \\
\text { Cerebral palsy } \\
\text { Congenital heart disease } \\
\text { Feeding problem } \\
\text { Otitis media } \\
\text { Congenital heart disease }\end{array}$ \\
\hline
\end{tabular}

\section{Infants}

Details of the infants studied are shown in Table $I$. They were aged between 2 weeks and 10 months and were in hospital with disorders not causing diarrhoea. All needed feeding by tube and none had received antibiotics for 2 weeks before intubation. Informed consent was obtained from the parents of all infants studied.

\section{Materials and methods}

Sampling technique. Duodenal contents were sampled with a long polyethylene feeding catheter (Argyl $5 F G$, length $91 \mathrm{~cm}$ ). Sterile catheters were supplied by the manufacturer and a new catheter was used for each intubation. The distal end of the catheter was teased out by flaming, threaded through the central canal of a gold bead (length $4 \mathrm{~mm}$, weight $230 \mathrm{mg}$ ), and knotted. Care was taken to maintain the sterility of the gold bead 
and catheter during these manipulations. The gold bead was used to weight-direct the catheter tip, gold being selected for its density and nontoxic properties (Rhea and Kilby, 1970). To enable aspiration of intestinal juice, three small holes were cut in the wall of the distal $2.5 \mathrm{~cm}$ of the catheter, with the most distal hole $2 \mathrm{~mm}$ from the gold bead.

Before intubation nose and throat swabs were taken and cultured in order to identify organisms that may have been carried by the catheter into the stomach and duodenum. The catheter was then gently passed through the nasopharynx into the stomach in identical manner to the introduction of an intragastric feeding tube. Gastric juice was aspirated and the first sample was discarded to clear the catheter of secretions from the nose and throat. A second sample of $1 \mathrm{ml}$ was aspirated and $0.1 \mathrm{ml}$ was placed in $1.9 \mathrm{ml}$ of transport medium (heart infusion broth $+10 \%$ glycerol). The patient was then turned on the right side and the catheter advanced until 35 to $40 \mathrm{~cm}$ had been inserted. The proximal end of the catheter was capped and fixed to the cheek by strapping and the gold bead was allowed to pass into the duodenum by normal peristalsis. After one hour, bile-stained fluid could be aspirated from the catheter and the position of the catheter tip in the 2 nd- 4 th part of the duodenum was confirmed by screening. Duodenal juice was aspirated and the first $2 \mathrm{ml}$ were discarded to exclude contamination by gastric juice. The second sample was used for bacteriological culture and $0.1 \mathrm{ml}$ was placed in $1.9 \mathrm{ml}$ of transport medium. The catheter was then emptied by syringing through with 5 $\mathrm{ml}$ of air, was capped, and left in situ. Bacteriological culture of the gastric and duodenal juice was performed within 2 hours of sampling. Nose and throat swabs were immediately plated onto culture media.

Sampling regimen. Variation in the duodenal microflora may occur during the day, especially after a meal (Drasar, Shiner, and McLeod, 1969). The following sampling regimen was therefore devised in relation to feeding over a 24-hour period, and was used in all 13 infants. A milk feed was given at 8.00 a.m., the catheter was inserted into the stomach at 9.00 a.m., and the first duodenal sample was taken at 10.00 a.m., 2 hours after the milk feed. The infants were given their next feed at 12 noon. As the diet of each infant varied and dietary constituents might induce differences in the flora, a standard feed of $5 \%$ dextrose was given at 2.00 p.m. 2 hours later, at 4.00 p.m., the second duodenal sample was aspirated. The catheter was left in situ and the infants were fed normally until midnight. The third sample of duodenal juice was aspirated at 9.00 a.m. on the following morning, after a 9-hour fast. After this sample the position of the gold bead in the duodenum was again confirmed by screening and the catheter was then removed.

Microbiological methods. Both selective and nonselective media were used in this study. The media and the types of organisms cultured on each medium are shown in Table II.

Nose and throat swabs. Nose and throat swabs were immediately plated onto the media shown in Table II and the growth of each organism was estimated as +, ,+++++ . Anaerobic culture of nose and throat organisms was not attempted.

Gastric and duodenal juice. The 1 in 20 dilutions of gastric or duodenal juice in transport medium were delivered promptly to the laboratory. Within 2 hours aliquots of $0.5 \mathrm{ml}$ were removed and serial tenfold dilutions were made of each aliquot in glucose broth. The culture media shown in Table II were then plated with $0.1 \mathrm{ml}$ of each dilution and all plates were incubated for the time intervals indicated. Anaerobic bacteria were grown on blood agar plates in a modified McIntosh and Fildes jar (Baird \& Tatlock, London) containing a 'cold catalyst'. Air in the jar was pumped out and replaced by an atmosphere of hydrogen. The hydrogen was then pumped out and the jar refilled with hydrogen and $10 \% \mathrm{CO}_{2}$ before incubating at $37^{\circ} \mathrm{C}$ for periods up to 6 days. The presence of Bacteroides sp. was confirmed by Gram stain and subculture. Nonsporing, Gram-negative, strictly anaerobic rods were classified as Bacteroides sp. Aerobic organisms were identified by colonial appearance, growth on culture media, morphology, staining, and by standard biochemical reactions (Cowan and Steel, 1965). The quantitative results of bacteriological culture were expressed as the

TABLE II

Microbiological culture techniques

\begin{tabular}{|c|c|c|c|}
\hline Culture medium & Organisms isolated by media & Incubation time (dy) & Dilutions plated \\
\hline $\begin{array}{l}\text { Blood agar } \\
\text { Blood agar } \\
\text { MacConkey agar } \\
\text { Sabouraud's dextrose agar } \\
\text { Chocolate agar } \\
\text { Blood agar + gentian violet } \\
\text { de Man, Rogosa, and Sharpe's } \\
\text { medium (1960) }\end{array}$ & $\begin{array}{l}\text { Aerobes } \\
\text { Anaerobes } \\
\text { Enterobacteriaceae, enterococci } \\
\text { Yeasts and moulds } \\
\text { Aerobes, in particular Haemophilus } \\
\text { and pneumococci } \\
\text { Streptococci, in particular } \\
\text { Streptococcus pyogenes } \\
\text { Aerobic lactobacilli }\end{array}$ & $\begin{array}{l}1-2 \\
2-6 \\
1 \\
2-5 \\
1-2 \\
1-2 \\
2-5\end{array}$ & $\begin{array}{c}10^{-1}-10^{-5} \\
10^{-1}-10^{-5} \\
10^{-1}-10^{-5} \\
\text { (also nose and throat swabs) } \\
10^{-1} \\
\text { Nose and throat swabs } \\
\text { Nose and throat swabs } \\
10^{-1}-10^{-5}\end{array}$ \\
\hline
\end{tabular}


$\log _{10}$ of the viable organism count $/ \mathrm{ml}$ intestinal juice. Thus, 5000 organisms $/ \mathrm{ml}=3 \cdot 7 \log _{10}$ viable organisms $/ \mathrm{ml}$ of juice.

\section{Results}

Nose and throat swabs. Bacteriological cultures from the nose and throat swabs showed a wide variety of organisms, with coagulase-negative staphylococci being isolated most frequently from the nose and Streptococcus viridans from the throat (Fig. 1 and 2). Coliforms were also present.

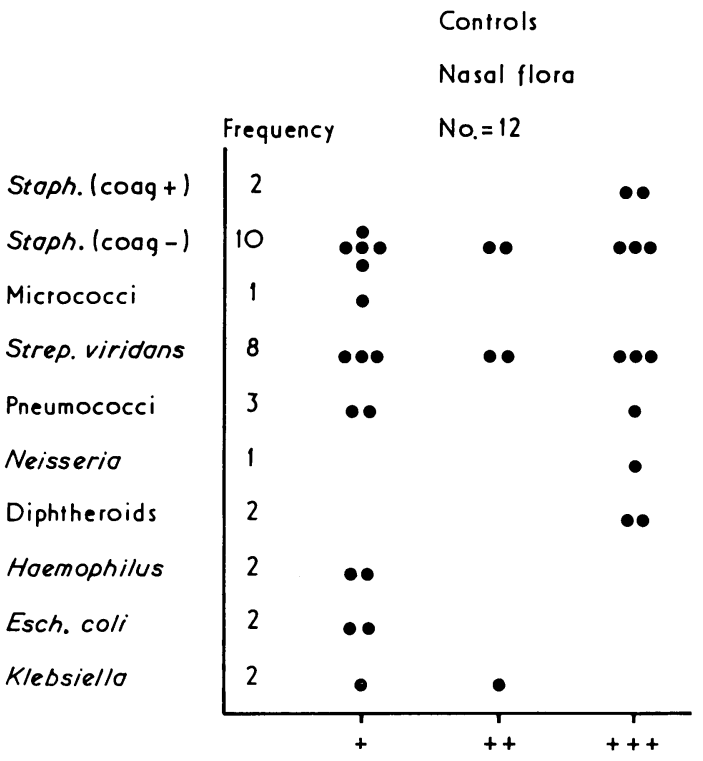

FIG. 1.-Micro-organisms isolated from the noses of 12 infants.

Gastric juice. Many of the organisms found in the nose and throat were also isolated from the gastric juice (Fig. 3), and these findings may be related to the relatively short postprandial period before gastric sampling took place. Coagulasenegative staphylococci, Strep. viridans, and coliforms were the organisms most frequently isolated. Only one sample of gastric juice was sterile.

Duodenal juice. The first sample of duodenal juice showed marked bacteriological differences from the gastric juice (Fig. 4). In 7 out of 13 infants it was sterile and coliforms were not isolated, though these organisms were present in many of the gastric samples taken shortly beforehand. In those infants in whom organisms were present in the duodenum, the types isolated were similar to those

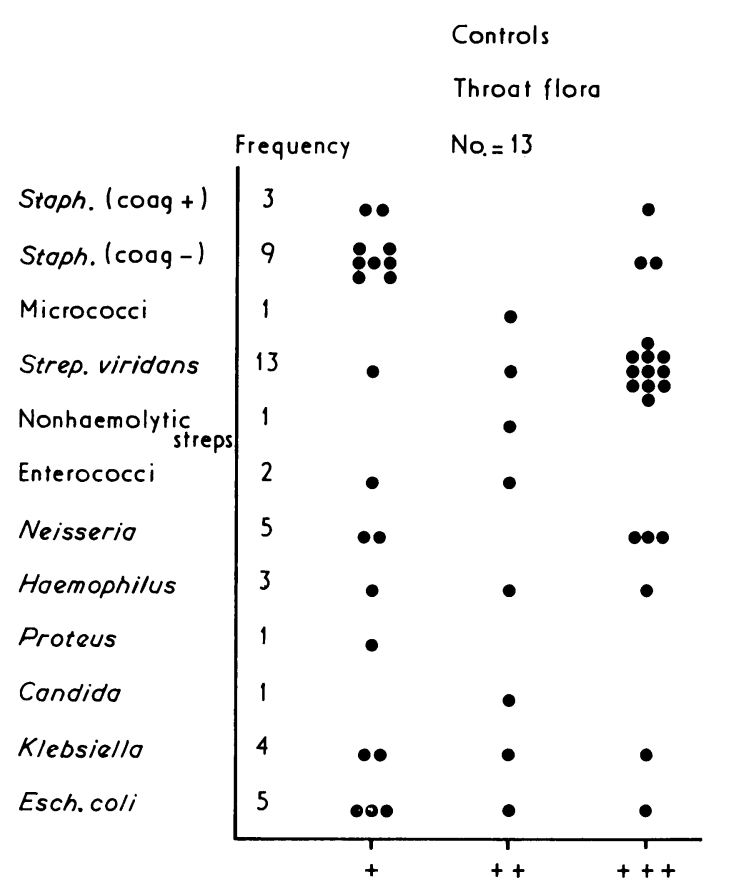

FIG. 2.-Micro-organisms isolated from the throats of 13 infants.

found in the nose, throat, and stomach. Quantitative results from the gastric and duodenal juice are shown in Table III.

Effect of prolonged intubation. The effect of prolonged duodenal intubation on the microflora over a 24-hour period was studied in all 13 infants. As changes in the reported microflora might be due to proliferation of organisms within the sampling tube, the first two samples of duodenal juice taken on each occasion were not used for bacterial culture.

\section{TABLE III}

Variety and total numbers of organisms isolated from the gastric juice and first samples of duodenal juice

Gastric juice

No. of infants

Sum of total organism count in all infants $\quad 8.4 \log _{10} / \mathrm{ml}$

Mean total count in all infants

No. of samples sterile

Types of organisms isolated

No. of samples which grew coliforms

Duodenal juice

No. of infants

Sum of total organism count in all infants

Mean total count in all infants

No. of samples sterile

Types of organisms isolated

No. of samples which grew coliforms
$7 \cdot 3 \log _{10} / \mathrm{ml}$ 1

15

6

13

$6 \cdot 8 \log _{10} / \mathrm{ml}$ $6 \cdot 0 \log _{10} / \mathrm{ml}$

7

8

0 


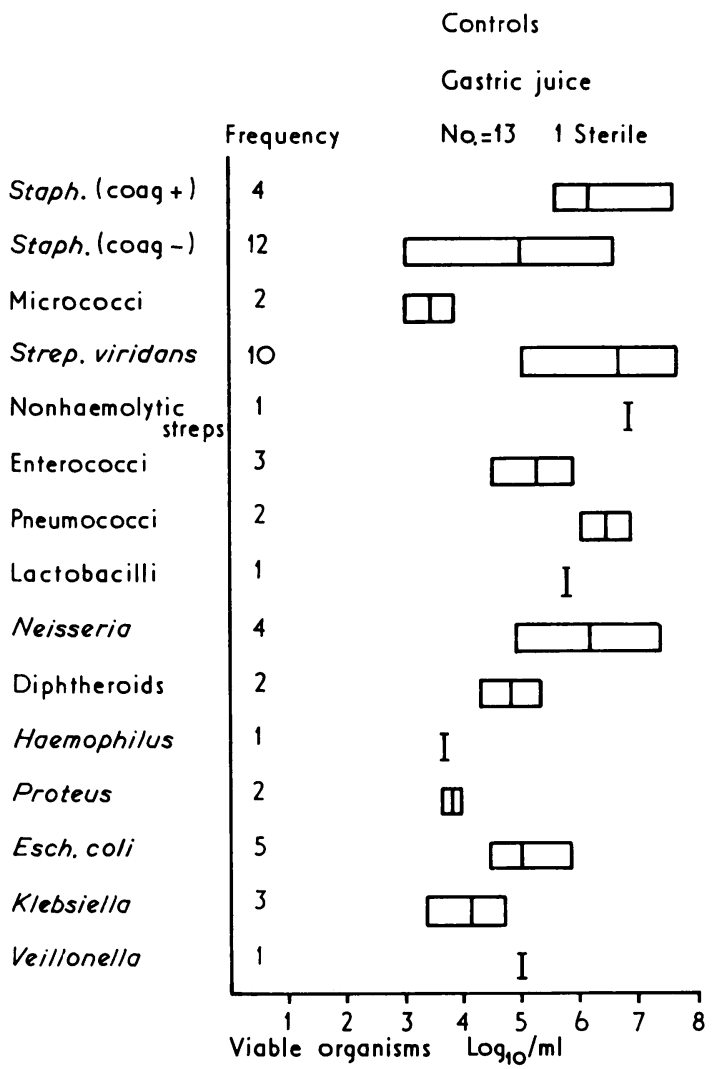

FIG. 3.-Micro-organisms isolated from the gastric juice of 13 infants.

The bacteria grown from the duodenal samples taken at the three sampling periods are shown in Fig. 4,5 , and 6 , respectively. The sum of the total bacterial count in each instance increased slightly from $6.8 \log _{10} / \mathrm{ml}$ initially, to $7.07 \log _{10} / \mathrm{ml}$ in the samples taken after 24 hours. The number of sterile samples decreased from 7 out of 13 in the initial 10.00 a.m. samples to 6 out of 12 after 9 hours of intubation, and after 24 hours only 2 out of 11 were sterile. Esch. coli were absent in the initial samples, but after 9 hours of intubation the Esch. coli count, expressed as a percentage of the total count, increased to $20 \%$, and after 24 hours $55 \%$ of the organisms present were Esch. coli. An increase in the percentage of Klebsiella sp. was also found in 4 cases (Fig. 7).

\section{Discussion}

The first sample of duodenal juice collected at 10.00 a.m. was sterile in 7 of the 13 infants studied. Gram-positive and Gram-negative aerobic

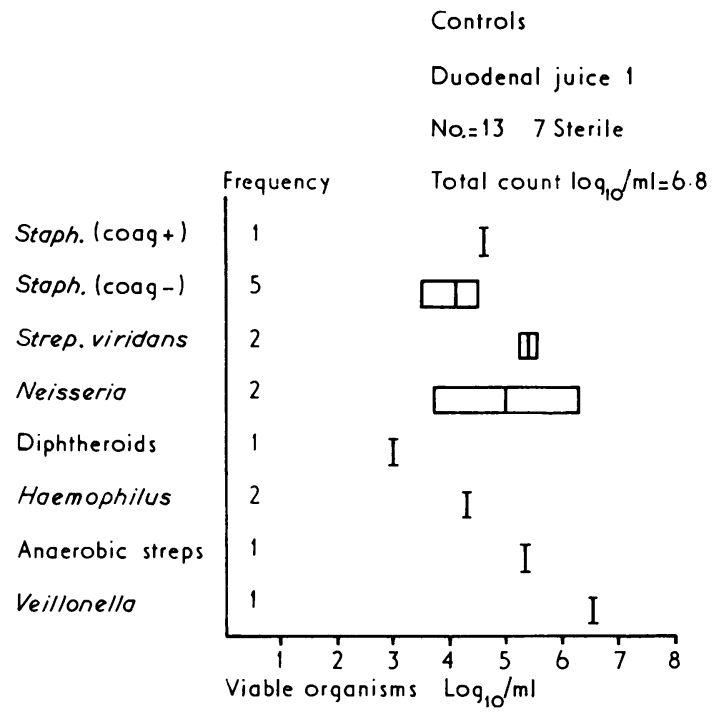

FIG. 4.-Micro-organisms isolated from the duodenal juice of 13 infants.

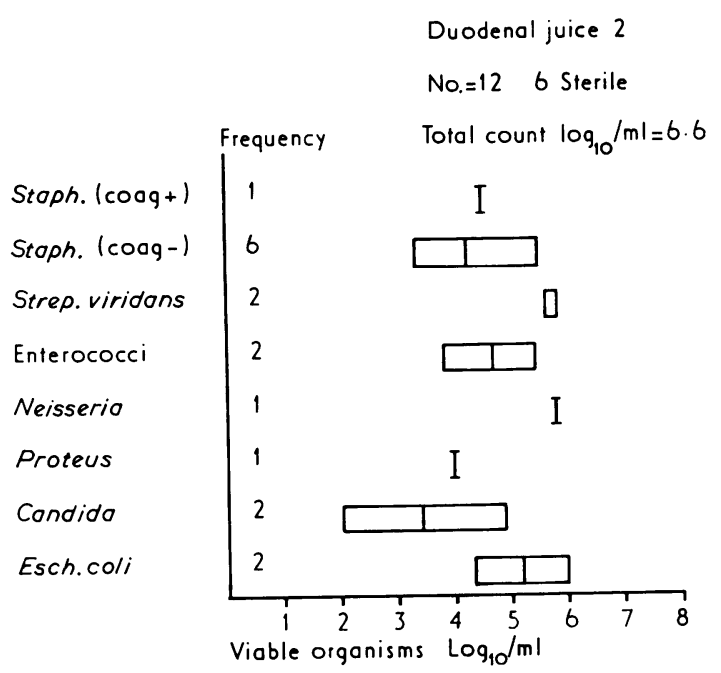

FIG. 5.-Micro-organisms isolated from the duodenal juice of 12 infants after 9 hours of intubation.

organisms were present in the 6 remaining infants, and these organisms were also isolated from the nose, throat, and gastric juice of the same 6 infants. This finding suggests contamination of the duodenum by organisms originating from higher up the gastrointestinal tract. Temporary contamination of the duodenum by ingested food has been shown by Drasar et al. (1969), the 


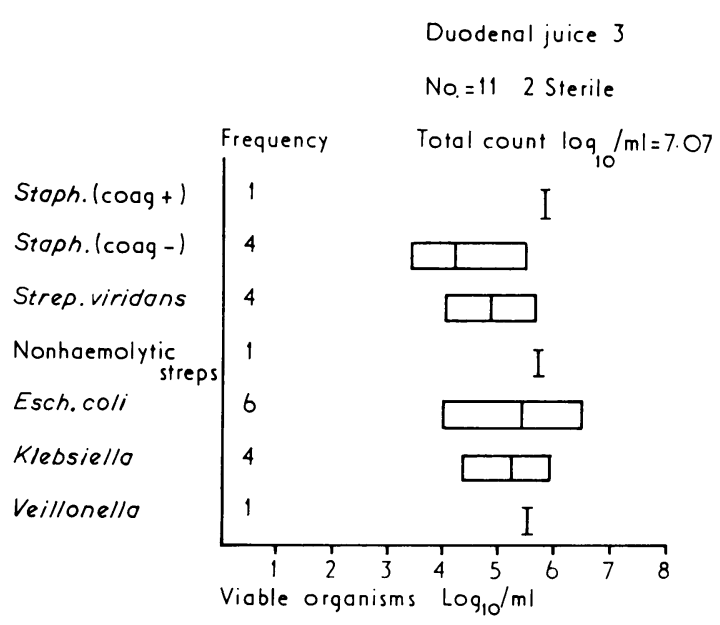

FIG. 6.-Micro-organisms isolated from the duodenal juice of 11 infants after 24 hours of intubation.

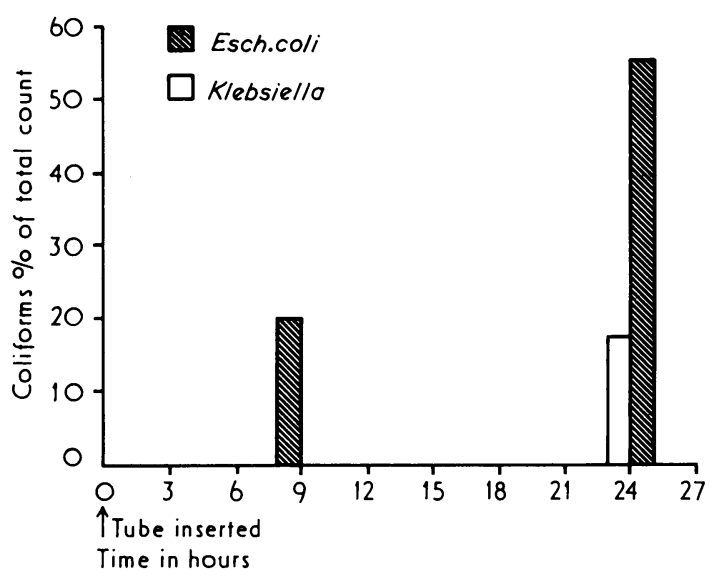

FIG. 7.-Increase in coliform count expressed as a percentage of the total count, with prolonged intubation.

organisms passing through in wave-like fashion after meals. Obligate anaerobes such as Veillonella and anaerobic streptococci were also occasionally isolated from the duodenal samples. Unlike other workers (Gorbach et al., 1967; Hamilton et al., 1970), we have been unable to show a constant Gram-positive flora in the duodenum, nor have we been able to assign an upper numerical limit of organisms $/ \mathrm{ml}$ of duodenal juice, above which the total bacterial count becomes abnormal. Kalser et al. (1966) suggested an upper limit of $10^{3} / \mathrm{ml}$ of small intestinal juice. In those infants in this study in whom organisms were isolated from the duodenum, the total count ranged from $10^{3}-10^{6} / \mathrm{ml}$ duodenal juice $(3 \cdot 0-6 \cdot 0$ $\left.\log _{10} / \mathrm{ml}\right)$.
Esch. coli and Klebsiella were absent from the first samples of duodenal juice of all infants, though these organisms were present in some specimens of gastric juice sampled shortly beforehand. The sampling catheter in this investigation was allowed to pass into the duodenum by normal peristalsis, permitting sufficient time for mechanisms clearing the intestine of coliforms to act (Dack and Petran, 1934; Dixon, 1960). If duodenal samples had been taken after rapid intubation, it is likely that gastric juice containing coliforms would have been carried into the duodenum, and coliforms would have been isolated. Some workers have described low concentrations of coliforms in the upper small intestine of normal subjects (Kalser et al., 1966), while others have failed to isolate these organisms (Shiner et al., 1963). Gorbach et al. (1967) sampled from many areas in the proximal small intestine and also failed to show a coliform flora. High concentrations of coliforms have been described in the duodenum of infants with chronic diarrhoea and carbohydrate intolerance (Coello-Ramirez, Lifshitz, and Zuniga, 1972) and the growth of coliforms from the upper small intestine may therefore indicate the presence of a pathogenic microflora.

The importance of precise definition of sampling and culture techniques in a study of the gastrointestinal microflora has been previously stressed, for different techniques may give rise to widely differing results (Hamilton et al., 1970). Many small intestinal sampling methods have been devised, including needling the small bowel at laparotomy (Anderson and Langford, 1958) or at necropsy (Blacklock, Guthrie, and MacPherson, 1937). Other methods include the use of automatic sampling capsules, either attached (Shiner, 1963) or unattached to a tube (Van der Reis, 1925; Hirtzmann and Reuter, 1963) and peroral intubation using a long open-ended polyethylene or rubber tube (Gorbach et al., 1967). The organisms isolated using the long open-ended tube have been shown to compare favourably with the Shiner capsule (Kalser et al., 1966) and with needle aspirations at laparotomy (Anderson and Langford 1958).

Results produced by the long tube method of sampling have been questioned on the following four points (Cregan and Hayward, 1953).

(1) The tube becomes contaminated by organisms acquired from higher levels in the gastrointestinal tract.

(2) Micro-organisms in the small intestine may multiply if the tube is left in position for an extended period of time, the tube acting as a foreign body.

(3) The position of the tip of the tube may be 


\section{Bacterial microflora of the upper gastrointestinal tract in infants without diarrhoea}

difficult to determine, and therefore the part of the small intestine sampled.

(4) Alteration of intestinal motility may be produced by the tube.

These factors have been studied in experiments with dogs and in man and the validity of the long open-ended tube method has been established by Gorbach et al. (1967). These writers showed that prolonged intubation of the small intestine did not produce a rise in the total bacterial count over a period of 24 hours. In our study the total bacterial count rose only slightly from $6 \cdot 8-7 \cdot 02 \log _{10} / \mathrm{ml}$ after 24 hours of intubation, but a marked qualitative change in the microflora occurred during that time. The number of Esch. coli in the duodenum, expressed as a percentage of the total count, had increased after 9 hours of intubation and increased further by 24 hours. After 24-hour intubation Klebsiella were also frequently isolated. This qualitative change confirms the suggestion of Cregan and Hayward (1953) that the duodenal microflora may be altered by prolonged intubation, and suggests that prolonged intubation should not be used in future bacteriological studies if such results are to be avoided.

We thank Dr. K. B. Rogers, Mr. G. A. Brown, and Mr. A. H. Wright for help and advice with this project; and also the consultants and nursing staff of the Birmingham Children's Hospital. D.N.C. was supported by a grant from the Endowment Fund of the United Birmingham Hospitals and J.R. by a grant from the Medical Research Council.

\section{REFERENCES}

Anderson, C. M., and Langford, R. F. (1958). Bacterial content of the small intestine of children in health, in coeliac disease, and in fibrocystic disease of the pancreas. British Medical fournal, 1, 803.

Barbero, G. J., Runge, G., Fischer, D., Crawford, M. N., Torres, F. E., and György, P. (1952). Investigations of the bacterial flora, $\mathrm{pH}$ and sugar content in the intestinal tract of infants. fournal of Pediatrics, 40, 152.

Blacklock, J. W. S., Guthrie, K. J., and MacPherson, I. (1937). A study of the intestinal flora of children. Fournal of Pathology and Bacteriology, 44, 321.

Coello-Ramirez, P., Lifshitz, F., and Zuniga, V. (1972). Enteric microflora and carbohydrate intolerance in infants with diarrhea. Pediatrics, 49, 233.
Cowan, S. T., and Steel, K. J. (1965). Manual for the Identification of Medical Bacteria. Cambridge University Press, Cambridge.

Cregan, J., and Hayward, N. J. (1953). The bacterial content of the healthy human small intestine. British Medical fournal, 1, 1356.

Dack, G. M., and Petran, E. (1934). Bacterial activity in different levels of the intestine and in isolated segments of small and large bowel in monkeys and in dogs. Fournal of Infectious Diseases, 54, 204.

Davison, W. C. (1925). The duodenal contents of infants in health, and during and following diarrhea. American fournal of Diseases of Children, 29, 743.

de Man, J. C., Rogosa, M., and Sharpe, M. E. (1960). A medium for the cultivation of lactobacilli. Fournal of Applied Bacteriology, 23, 130.

Dixon, J. M. S. (1960). The fate of bacteria in the small intestine. Fournal of Pathology and Bacteriology, 79, 131.

Donaldson, R. M., Jr. (1968). Role of indigenous enteric bacteria in intestinal function and disease. In Handbook of Physiology Section 6, Vol. 5, p. 2807. Ed. by C. F. Code. American Physiological Society, Washington, D.C.

Drasar, B. S. (1967). Cultivation of anaerobic intestinal bacteria Fournal of Pathology and Bacteriology, 94, 417.

Drasar, B. S., Shiner, M., and McLeod, G. M. (1969). Studies on the intestinal flora. I. The bacterial flora of the gastrointestinal tract in healthy and achlorhydric persons. Gastroenterology, 56, 71 .

Gorbach, S. L. (1971). Intestinal microflora. Gastroenterology, 60, 1110.

Gorbach, S. L., Plaut, A. G., Nahas, L., Weinstein, L., Spanknebel, G., and Levitan, R. (1967). Studies of intestinal microflora. II. Microorganisms of the small intestine and their relations to oral and fecal flora. Gastroenterology, 53, 856.

Hamilton, J. D., Dyer, N. H., Dawson, A. M., O'Grady, F. W. Vince, A., Fenton, J. C. B., and Mollin, D. L. (1970). Assessment of significance of bacterial overgrowth in the small bowel. Quarterly fournal of Medicine, 39, 265.

Hirtzmann, M., and Reuter, G. (1963). Klinische Erfahrungen mit einer neuen automatisch gesteurerten Kapsel zur Gewinnung von Darminhalt und bakteriologische Untersuchungen des Inhalts höherer darmabschnitte. Medizinische Klinik, 58, 1408.

Kalser, M. H., Cohen, R., Arteaga, I., Yawn, E., Mayoral, L., Hoffert, W. R., and Frazier, D. (1966). Normal viral and bacterial flora of the human small and large intestine. New England Fournal of Medicine, 274, 500.

Rhea, J. W., and Kilby, J. O. (1970). A nasojejunal tube for infant feeding. Pediatrics, 46, 36.

Shiner, M. (1963). A capsule for obtaining sterile samples of gastrointestinal fluids. Lancet, 1, 532.

Shiner, M., Waters, T. E., and Gray, J. D. (1963). Culture studies of the gastrointestinal tract with a newly devised capsule. Results of tests in vitro and in vivo. Gastroenterology, 45, 625.

Van der Reis, V. (1925). Die darmbakterien der Erwachsenen und ihre klinische Bedeutung. Ergebnisse der Inneren Medizin und Kinderheilkunde, 27 .77.

Correspondence to Dr. D. N. Challacombe, Taunton and Somerset Hospital, Musgrove Park, Taunton, Somerset TA1 5DA. 